\title{
UNAUTHORIZED PRACTICE OF LAW: BANK PROHIBITED FROM PROVIDING ESTATE ANALYSIS SERVICE
}

The Ohio Supreme Court enjoined a national bank from providing "estate analysis" reports to prospective customers on the ground that this program involved the giving of legal advice by a lay institution. The decision affords salutary protection to the relevant public and professional interests which underlie the prohibition against the unauthorized practice of law.

$\mathrm{E}^{\mathrm{s}}$ STATE PLANNING has developed in recent years into a specialized service, largely because of the increasing intricacy of applicable tax law ${ }^{1}$ and the growing demand for specialization wrought by societal complexity. Its general purpose is the orderly arrangement of a person's assets so as to provide effectively for his own economic needs during his lifetime and for the needs of his dependents after his death. ${ }^{2}$ While the actual drafting of the requisite testamentary or trust instruments is now generally conceded to be the sole responsibility of the independent attorney, ${ }^{3}$ there is far

\footnotetext{
1 See Mclucas, Relations of Banks with the Bar, 30 Unauthordzed Practice News 189, 194 (1964); 39 N.Y.U.L. REv. $364-65$ (1964). For example, the 1948 Internal Revenue Act included a new provision entitling the estate of a taxpayer to deduct property passing to a surviving spouse in an amount up to one half of the adjusted gross estate. INT. REv. CODE OF 1954, $\$ 2056$. This "marital deduction" provision has introduced a multitude of considerations into the task of the estate planner who must now concern himself with the complex questions of whether and how to take the marital deduction. See generally Trachtman, Estate Planning 12.67 (1964).

2 American Bar Association Committee on Unauthorized Practice of the Law, Opinion 1959-A: Estate Planning, 45 A.B.A.J. 1296 (1959). Estate planning involves several steps: collection of full information about a client's affairs; analysis of a client's assets in terms of his own needs and those of his dependents and other intended beneficiaries; formulation of an integrated estate plan; and drafting of any necessary instruments as well as supervision over any other changes in the client's legal status pursuant to an implementation of the estate plan.

'See Arkansas Bar Ass'n v. Union Nat'1 Bank, 224 Ark. 48, 56-57, 273 S.W.2d 408, 413 (1954); Hobson v. Kentucky Trust Co., 303 Ky. 493, 505, 197 S.W.2d 454, 461, (1946); People v. Peoples Trust Co., 180 App. Div. 494, 167 N.Y. Supp. 767 (1917); State ex rel. Miller v. St. Louis Union Trust Co., 385 Mo. 845, 860, 868, 74 S.W.2d 348, 354, 359 (1934); National Conference Group, Statements of Principles with Respect to the Practice of Law: Banks with Trust Functions, reprinted in 3 MARtindale-Hubbell, LAw Directory 190A (1966). Contra, Merrick v. American Sec. \& Trust Co., 107 F.2d 271, 277 (D.C. Cir. 1939) (trust agreements); Cain v. Merchants Nat'I Bank \& Trust Co., 66 N.D. 746, 754-55, 268 N.W. 719, 723.24 (1936) (isolated instances of drafting); Umble's Estate, $117 \mathrm{~Pa}$. Super. 15, 177 Atl. 340 (1935) (preparation of only one will). A trust institution has been permitted to draft revocable, non-donative, and non-testamentary trust agreements. See, e.g., Detroit
} 
less agreement as to the line of demarcation between the respective roles of the lawyer and the trust officer in the vital analysis-andplanning phrase of estate practice. ${ }^{4}$ Yet this distinction must be made and recognized since performance by the trust officer of duties considered to be the function of the attorney constitutes the unauthorized practice of law..$^{5}$

This bank-bar conflict was the issue in the recent Ohio Supreme Court case of Green $v$. Huntington Nat'l Bank. ${ }^{6}$ The bank, authorized by the Federal Reserve Board to act in various fiduciary capacities, ${ }^{7}$ solicited inquiries from the general public about its trust and estate business and requested prospective customers to submit specific data concerning assets, family, and preferences concerning the course of property disposition at death. ${ }^{8}$ This data, after being examined, was "plugged into" certain standard trust provisions se-

Bar Ass'n v. Union Guardian Trust Co., 282 Mich. 216, 228-29, 276 N.W. 365, 369 (1937); 107 U. PA. L. REv. 398, 400 (1959).

1 The creation of a comprehensive estate plan is likely to require a working knowledge of the law of real and personal property, wills and decedents' estates, trusts and future interests, partnerships and corporations, federal and state taxation, and probate practice. Stressing this fact, the American Bar Association has taken the position that, except for general analysis and discussion, problems in this area demand the special competence of the outside, licensed attorney. American Bar Association Committee on Unauthorized Practice of the Law, supra note 2, at 1296. On the other hand, trust iustitutions have called attention to their skills and have urged recognition of their legitimate interest in the formative stage of estate planning as an integral part in the successful prosecution of their trust business.

s Recognizing the inability of the layman to deal effectively with legal problems, the early common law evolved restrictions designed to insure that those who argued cases in the courts and those who advised the public as to legal matters would be qualificd to do so by education and experience. See PoTter, Historical INTroduction TO ENGLISH LAW AND ITS INSTITUTIONS 82-86 (4th ed. 1958). See generally 1 PoLLOCK 8: Martland, The History of ENGLish Law 210-218 (2d ed. 1898). As licensing procedures were used to regulate qualifications for lawyers, there developed a corresponding prohibition against practice of law by the unlicensed. Today, statutes and/or court rules in all states forbid the unauthorized practice of law by laymen and corporations. See notes 14, 17 infra. For a helpful survey of the origin and development of the legal profession and of the unauthorized practice proscription, see vom Baur, An Historical Sketch of the Unauthorized Practice of Law, Unauthorized Practice News, Fall 1958, p. 1.

- 4 Ohio St. 2d 78, 212 N.E.2d 585 (1965).

IIn 1922 the Federal Reserve Board, pursuant to statutory authority, authorized the defendant bank to act as trustee, executor, administrator, guardian, assignee and receiver where the exercise of such powers was not in conflict with state or local law and to act in any other fiduciary capacity which competing corporations were allowed to assume by the laws of Ohio. See Act of Sept. 26, 1918, ch. 117, $\$ 2$ (k), 40 Stat. 968 (cited in Green as 12 U.S.C. $\$ 248(\mathrm{k})$ (1958)), repealed by Act of Sept. 28, $1962, \S 3,76$ Stat. 670 . This authorizing function was transferred from the Federal Reserve Board to the Comptroller of the Currency in 1962. Act of Sept. 28, 1962, \$ 1 (a), 76 Stat. 668, 12 U.S.C. § 92a (a) (1964).

${ }^{8}$ Brief for Appellant, p. 2; Brief for Appellee, pp. 4-5. 
lected and adapted to accord with the prospect's circumstances and needs. The result was sent to the prospect in the form of an "estate analysis" report containing estimates of federal and state tax liability, suggestions as to the form of asset ownership, and an indication of possible savings for the prospect if the bank's suggestions were implemented. ${ }^{9}$ Consultation with an attorney for the actual "planning" and the drafting of legal documents was strongly recommended. ${ }^{10}$ The bank made no charge for this service; its intention, however, was to induce the prospect to engage in estate planning with the bank as fiduciary. ${ }^{11}$

The plaintiffs, members of the unauthorized practice of law committee of the state bar association, ${ }^{12}$ succeeded in enjoining the bank from continuing the estate analysis program ${ }^{13}$ on the grounds that

${ }^{8}$ Brief for Appellant, pp. 2-3. See Brief for Appellee, pp. 6-12.

${ }^{20} 4$ Ohio St. 2d at 8I-82, 212 N.E.2d at 588. Since the practice of law encompasses the giving of legal advice (a necessary and implied element in the formulation of an estate plan), Land Title Abstract \& Trust Co. v. Dworken, 129 Ohio St. 23, 28,193 N.E. 650, 652 (1934), and the preparation of legal instruments, Judd v. City Trust \&e Sav. Bank, 133 Ohio St. 81, 87, 12 N.E.2d 288, 291 (1937), these services must be performed by an attorney under Ohio law. See note 17 infra.

${ }^{11} 4$ Ohio St. $2 \mathrm{~d}$ at 81,212 N.E.2d at 587.

${ }^{12}$ Nearly every state bar organization today has a special committee dealing with the practice of law by laymen and lay institutions. Organized efforts to combat unauthorized practice began in the 1910-1915 period which saw the creation of the first unauthorized practice committees by the Chicago and New York City bar asso. ciations. Increased awareness of the scope of this problem and the threat it posed led to the establishment in 1930 of the Committee on the Unauthorized Practice of Law by the American Bar Association. Otterbourg, A 1960 Resume; Unauthorized Practice of the Law, 46 A.B.A.J. 46, 47 (1960). A few years later the American Bar Association began publication of a periodical, the Unauthorized Practice News, to focus attention on lay activities in the traditional domain of the licensed attorney. The elimination of unauthorized practice has maintained a high priority in the programs of the national and state bar organizations. One fruit of this continuing campaign has been the institution of legal proceedings (or the submission of amicus curiae briefs in suits by other plaintiffs), with the usual objective being to obtain an injunction in order to stop or discourage the alleged practice of law by lay institutions or persons. See note 13 infra. The most frequent defendants in these actions (indicating the predominant areas of controversy) have included accountants and notaries, title companies, realtors, collection agencies, insurance companies, unions, and corporate fiduciaries. A collection of unauthorized practice cases through 1965 is contained in American Bar Foundation, Unauthorized Practice Source Book (rev. ed. 1965).

${ }^{23}$ The Court of Common Pleas dismissed the plaintiff's petition, finding that no specific advice had been given and that the plaintiffs, in showing only that the bank had disseminated general information and suggestions as an incident to its authorized fiduciary practice, had failed to sustain the burden of proving unlawful engagement in the practice of law. Green v. Huntington Nat'l Bank, No. 207, Franklin County Ct. C.P., Aug. 1962. The Ohio Court of Appeals reversed and held that while the reasonable use of illustrations analogous to a prospect's situation in an estate analysis presentation was unoffensive, the providing of specific legal information relating to spe- 
it involved the unauthorized practice of law. ${ }^{14}$ In upholding the injunction, the Ohio Supreme Court defined the practice of law as the repeated giving of legal advice to others with the expectation of receiving compensation. ${ }^{15}$ In the estate practice context, the court determined that the providing of specific legal information concerning the specific facts of an individual estate constituted the giving of legal advice, ${ }^{16}$ a service which the bank as a lay institution could not lawfully offer or hold itself out as offering..17 The injunc-

cific facts, which the court found to have occurred in the instant case, constituted the practice of law. Green v. Huntington Nat'l Bank, 3 Ohio App. 2d 62, 209 N.E.2d 228 (1964). Consequently, the bank was enjoined from "offering or providing to any person who seeks information or assistance in the analysis or planning of an estate, specific legal information in relation to the specific facts of a particular estate [and] . . from offering or providing specific comments or advice on the form of investments or on the management of assets in a particular estate, for the purpose of obtaining for a particular person ... a more beneficial estate condition in relation to the tax and other consequences of death upon such estate." Green v. Huntington Nat'I Bank, No. 7209, Franklin County Ct. C.P., Aug. 11, 1964. The bank was also prohibited by injunction from soliciting inquiry concerning such services. Ibid.

I* All fifty states have statutes controlling the practice of law. This legislation ranges in character from the general "integration acts" limiting the practice of law to members of the bar, to statutes laying down definitions either of the practice of law or of unauthorized practice. All such legislation is helpfully compiled and classified in American Bar foundation, Unauthorized Practice Statute Book (1961). See also Otterbourg, $A$ Study of Unauthorized Practice of Law, Unauthorized Practice News, Sept. 1951, p. 1 at 61-72. Criminal penalties are the most common statutory remedy afforded, with the practice of law by an unauthorized person constituting a misdemeanor. See, e.g., IND. ANN. STAT. \$ 4-3602 (1946); OHIO REv. CODE ANN. $\S 4705.99$ (Page Supp. 1965). The most effective remedy, however, has been the injunction, restricting or prohibiting future acts. See, e.g., ConN. Gen. STAT. ANN. \$ 51-88 (1960); N.C. GEN. STAT. \$ 84-37 (1965). A variety of other forms of statutory and non-statutory judicial relief have been used, among which are the quo warranto proceeding, civil or criminal contempt of court decree, judicial inquiry, declaratory judgment or advisory opinion, writ of prohibition, and award of damages for negligence. See American Bar foundation, Unauthorized Practice Source Book 19.44 (rev. ed. 1965); Sanders, Procedures for the Punishment or Suppression of Unauthorized Practice of Law, 5 LAw \& Contemp. Prob. 135 (1938); Note, 62 Colum. L. Rev. 501 (1962).

Though there has been some confiict in the decisions, the judicial branch of government has generally been accorded the primary responsibility for defining and regulating legal practice, with the legislature recognized as performing a supplementary role. See, e.g., Hoffmeister v. Tod, 349 S.W.2d 5, 11 (Mo. 1961) (en bauc) (legislature may aid court by penalizing unauthorized practice but cannot interfere with the court's inherent power); West Virginia State Bar v. Earley, 144 W. Va. 504, 529-35, 109 S.E.2d 420, 436-39 (1959) (regulation inherently a judicial function). Cf. Barr v. Watts, 70 So. 2d 347 (Fla. 1953) (concurrent function); Detroit Bar Ass'n v. Union Guardian Trust Co., 282 Mich. 216, 225-28, 276 N.W. 365, 368-69 (1937) (separate judicial and legislative responsibilities with some areas of concurrence). See American Bar foundation, Unauthorized Practice Statute Book 1-5 (1962).

${ }^{15} 4$ Ohio St. $2 \mathrm{~d}$ at 81,212 N.E.2d at 587.

10 Id. at $80.81,212$ N.E.2d at 587 .

${ }^{27}$ Legislation in Ohio prohibits anyone who has not been admitted to the bar 
tion contained the proviso, however, that it was permissible for the bank to disclose its recommendations, specific or otherwise, to counsel for a prospective trust customer. ${ }^{18}$

In prior cases in which this or a related issue has arisen, several tests have been resorted to as means of distinguishing the sphere of permissible estate practice from that of the practice of law. For example, where preliminary information of a legal nature given to trust department customers is merely a service "incidental" to a bank's trust business, no unauthorized practice of law will result..

by order of the Ohio Supreme court from practicing law or conducting litigation in which he is not a party. OHo REv. Code ANN. $\$ 4705.01$ (Page 1954). A fine or imprisonment may be imposed on any unlicensed person holding himself out as authorized to practice law. OHro REv. CODE ANN. \$ 4705.99 (Page Supp. 1964). These provisions have been enforced against corporations, which are unable by definition to satisfy the "personal" requirements for admission to the bar. Land Title Abstract \& Trust Co. v. Dworken, 129 Ohio St. 28, 29-30, 198 N.E. 650, 653 (1934). Ohio is among the states which acknowledge broad judicial power in the governance of unauthorized practice. See note 14 supra; Note, 33 U. Cinc. L. REv. 401-06 (1964).

${ }^{18} 4$ Ohio St. 2d at 83, 85, 212 N.E.2d at 588, 590. The injunction of the court of apeals was further modified by the elimination of the prohibition concerning advice on the management of investments and assets, see note 13 supra, on the grounds that such activity may or may not fall within the proscription against unauthorized practice and that any illegal aspects were adequately encompassed by the rest of the judgment. 4 Ohio St. $2 \mathrm{~d}$ at 84,212 N.E.2d at 589. See Brief for Appellant, pp. 6-7.

${ }^{19}$ Merrick v. American Sec. \& Trust Co., 107 F.2d 271, 276.77 (D.C. Cir. 1939). Central to this concept is the idea that an activity which is "incidental" is both subordinate to and intimately connected with the primary, legitimate business of the lay person or corporation.

The "incidental services" doctrine has had currency in other areas of unauthorized practice controversy, see e.g., Ingham County Bar Ass'n v. Walter Neller Co., 342 Mich. 214, 228-30, 69 N.W.2d 713, 719-21 (1955) (conveyancing by real estate broker), and has been advanced particularly to justify certain practices of corporate fiduciaries, see, e.g., Merrick v. American Sec. \&. Trust Co., supra at 273 (handling of uncontested probate matters; preparation of trust agreements using standard forms); Judd v. City Trust \& Sav. Bank, 133 Ohio St. 81, 89-94, 12 N.E.2d 288, 292-94 (1937) (appearances in probate court; drafting of papers incident to administration of trust). The theory by which these acts are deemed lawful is that the practice of law necessarily imphes the rendering of services for another, and that in the administration of a trust or estate the fiduciary is acting primarily for itself. See Judd v. City Trust \& Sav. Bank, supra at 89-94, 12 N.E.2d at 292-93. Other courts and commentators have criticized the soundness of the second step in this syllogistic reasoning, arguing that a fiduciary is, by any proper interpretation, acting on behalf of the beneficiaries of a trust (or devisees of an estate) and therefore can be guilty of practicing law. See Arkansas Bar Ass'n v. Union Nat'l Bank, 224 Ark. 48, 51.52, 273 S.W.2d 408, 410-11 (1954); 43 MINN. L. REv. 827, 829-30 (1959); 32 So. CAL. L. REV. 425, 427-28 (1959).

Even when recognized as valid, the incidental services doctrine is subject to certain limitations: A lay person or corporation may not delve into any matter involving a complex issue of law. Gardner v. Conway, 234 Minn. 468, 480-81, 48 N.W.2d 788 $795-96$ (1951). A bank may perform such services incidental to its fiduciary business 
Such activity is viewed as being merely concomitant to the prospective and authorized employment of the bank as fiduciary and hence is not considered a part of the practice of law. ${ }^{20}$ However, in a number of jurisdictions, where the services, although incidental, are rendered for compensation, the court may find the transaction unlawful..$^{21}$

as filing various trust and estate applications, petitions, accounts, inventories and distributions in a probate court and as preparing tax returns, so long as such conduct does not involve problems the resolution of which would commonly be regarded as constituting the practice of law. State Bar Ass'n v. Connecticut Bank \& Trust Co., 146 Conn. 556, 563-64 n.3, 153 A.2d 453, 457 n.3 (1959), modifying 21 Conn. Supp. 42, 144 A.2d 347 (Super. C. 1958) on remand from 145 Conn. 222, 140 A.2d 863 (1958). Finally, while some courts would permit a realtor to draft an instrument conveying land in the course of his business, they would extend this right only to include mere clerical entries on "simple documents." See 17 AlA. L. REv. 360, 366 (1965) and cases cited. But see Clark v. Reardon, 231 Mo. App. 666, 670-71, 104 S.W.2d 407, 410 (1937), rejecting any test based on a "simple-complex instrument" distinction.

The characterization of acts as "incidental services" is also important in a jurisdiction exempting certain such services from the scope of its unauthorized practice ban. See e.g., N.J. STAT. ANN. $\$ \S 2 A: 170-81$ (a) to -81 (c) (1953).

${ }^{20}$ Merrick v. American Sec. \& Trust Co., supra note 19, at 274-77.

21 The element of compensation is sometimes included in the statutory definition of unauthorized practice. The statute in force in Missouri proscribing unauthorized practice, Mo. ANN. STAT. $\$ 484.020$ (1949), incorporates by reference another section defining "law business" as the "advising or counseling for a valuable consideration of any person, firm, association, or corporation as to any secular law or the drawing or procuring of or assisting in the drawing for a valuable consideration of any paper, document or instrument affecting or relating to secular rights." Mo. ANN. STAT. $\S 484.010 .2$ (1949). (Emphasis added.) In this jurisdiction a real estate broker was permitted to prepare simple trust deed and general warranty deed forms in closing transactions on an "incidental service" rationale, but with the caveat that the charging of any separate fee would convert them into the unauthorized practice of law. Hulse v. Criger, 363 Mo. 26, 43-44, 247 S.W.2d 855, 861 (1952). See Paul v. Stanley, 168 Wash. 371, 12 P.2d 401 (1932). In several cases, the court itself has injected the requirement that compensation be found before any sanction be imposed on a layman for performing occasional or "incidental" legal services. See In re Eastern Idaho Loan \& Trust Co., 49 Idaho 280, 286, 288 P. 157, 159 (1930); In re Opinion of the Justices, 289 Mass. 607, 615, 194 N.E. 313, 317 (1935); Fitchette v. Taylor, 191 Minn. 582, 584, 254 N.W. 910, 911 (1934); Cain v. Merchants Nat'l Bank \& Trust Co., 66 N.D. 746, 752-53, 268 N.W. 719, 722-23 (1936). If not a per se incriminating factor, compensation may be accorded evidentiary weight as showing that the legal services in question were not merely ancillary to some primary and lawful activity but rendered, in the view of the parties, as part of a separate business or occupation. See Merrick v. American Sec. \& Trust Co., supra note 19, at 276 n.19; State ex rel. Fatzer v. Schmitt, 174 Kan. 581, 585-86, 258 P.2d 228, 233-34 (1953). As the court of appeals in Green recognized, payment of a fee may also serve the purpose of raising the transaction above a de minimis level, thereby making it of "sufficient [importance] to warrant legal repression." 3 Ohio App. 2d at 64-65, 209 N.E.2d at 230.

Whether given application as a statutory or court-imposed criterion, the element of consideration or compensation has been broadly construed to encompass any direct or indirect economic benefit, such as the appointment of a bank or trust company as fiduciary. See State ex rel. Miller v. St. Louis Union Trust Co., 335 Mo. 
Another criterion to delimit the area of unauthorized practice was suggested in a recent Oregon case ${ }^{22}$ with a factual situation closely analogous to that in Green..$^{23}$ There the court reasoned that the estate planning advice furnished to customers of defendant corporation required the application of legal principles in more than an insubstantial way and therefore constituted the practice of law..$^{24}$ Under this test, even though the services are "incidental" to a lawful business, a violation will presumably occur if they are deemed substantial in nature.

Finally, the specific-general information dichotomy achieved in Green is not itself without supporting authority. The American Bar Association's Committee on Unauthorized Practice excluded from its characterization of allowable estate practice for laymen the "specific application [of laws affecting estate disposition] ... to a particular estate or individual situation." 25

845, 860, 74 S.W.2d 348, 354 (1934) (statute defined law business as necessarily including receipt of valuable consideration). Moreover, this benefit may be identified in the total commission or profit received for the entire transaction, of which the legal service itself was a minor but integral part. See Hill, Real Estate Brokers and the Courts, 5 LAw \& Contemp. Pros. 72, 76-77 (1938).

22 Oregon State Bar v. John H. Miller \& Co., 235 Ore. 341, 385 P.2d 181 (1963).

${ }^{33}$ Defendants in the Miller case were a corporation, Executive Estate Planners, and its president who had been offering a financial and estate planning service to customers. Company salesman solicited inquiries as to this service, which consisted of an cstate analysis suggesting the employment of various legal devices such as use of the marital deduction and inter vivos and testamentary trusts to minimize tax liability. Id. at 343-44, 385 P.2d at 181-82. The individual defendant unsuccessfully contended that this advice was merely incidental to his primary business of selling insurance. Ibid.

24Id. at $344-45,385$ P.2d at 182-83. Other courts have advanced similar definitional criteria. An Illinois court approved a concept of the practice of law which included extra-court services such as the dissemination of advice requiring the use of any legal skills or knowledge. Chicago Bar Ass'n v. Financial Planning, Inc., Case No. 53-S 10001, Ch., Super. Ct. Cook County, March 1, 1958 (reported in Unauthorized Practice News, June 1958, p. 29). The court's injunction was issued to prohibit the preparation of confidential financial reports comprising "an elaborate and detailed program for the devolution of the estate of the customer." Id. at 31. In another suit, a Kentucky court applied a judicial definition of the practice of law promulgated pursuant to statutory authorization: the practice of law is any service consisting of legal advice or knowledge communicated for the consideration and in respect to rights, duties, obligations, and liabilities of the party requesting such service. Hobson v. Kentucky Trust Co., 303 Ky. 493, 497, 197 S.W.2d 454, 457 (1946).

${ }^{25}$ American Bar Association Committee on Unauthorized Practice of the Law, supra note 2, at 1296. Cases dealing with acts of trust companies in general as the practice of law are collected in Annot., 69 A.L.R.2d 404 (1960).

Other judicial referents have been suggested by which to distinguish the practice of law from permissible lay business: an unlicensed person may not perform any acts "commonly understood to be the practice of law," State Bar Ass'n v. Connecticut Bank \& Trust Co., 145 Conn. 222, 234, 236, 140 A.2d 863, 870, 871 (1958), modifying 
Critics of the bar have charged that the application of these various tests to proscribe unauthorized practice has been motivated by a desire to preserve a lucrative monopoly over an employment which could adequately be discharged in part by lay specialists. ${ }^{26}$ While a concern for the protection of the financial and professional integrity of the bar is undoubtedly one motivating factor (though usually an unarticulated one) for the restrictions placed around legal practice, ${ }^{27}$ the predominant objective is protection of the public. ${ }^{28}$ The exclusion from legal practice of those who have not met the bar's requirements of education and character is designed to guarantee the public a reasonable level of competence and a high standard of ethical reliability. ${ }^{29} \mathrm{~A}$ client is assured that the advice he receives from his attorney is derived solely from consideration of his best interests, since the attorney must not only pass moral character scrutiny to gain admission to the bar but after admission is bound by a code of professional conduct prescribing undivided loyalty to the client by whom he is retained. ${ }^{30}$

20 Conn. Supp. 248, 131 A.2d 646 (Super. Ct. 1957); see People v. Title Guar. \& Trust Co., 227 N.Y. 366, 125 N.E. 666 (1919). Public convenience may validate certain conveyancing and legal advice provided by laymen. Conway-Bogue Realty Inv. Co. v. Denver Bar Ass'n, 135 Colo. 398, 417-18, 312 P.2d 998, 1007 (1957); Cowern v. Nelson, 207 Minn. 642, 647, 290 N.W. 795, 797 (1940). Contra, Hexter Title \& Abstract Co. v. Grievance Comm., 142 Tex. 506, 519-20, 179 S.W.2d 946, 953 (1944). For an excellent treatment of the various principles utilized by the courts in deciding unauthorized practice cases, see Johnstone, The Unauthorized Practice Controversy, $A$ Struggle Among Power Groups, 4 KAN. L. REv. 1, 6-22 (1955). See generally Hicks \& Katz, The Practice of Law by Laymen and Lay Agencies, 41 YAlE L.J. 69, 71 (1931); Comment, 2 S.D.L. REv. 104 (1957); Note, 26 Fordham L. REv. 163 (1957).

${ }^{20}$ See Hicks \& Katz, supra note 25, at 71; Note, 45 CoRNelc L.Q. 126, 134 (1959).

${ }^{27}$ See Llewellyn, The Bar's Troubles, and Poultices-and Cures?, 5 LAw \& CoNTEMP. Prob. 104, 109-14 (1938); 48 A.B.A.J. 99 (1962); 35 OHIo BAR 229, 230 (1962).

28 "The bar arose out of a public demand for the exclusion of those who assumed to practice law without adequate qualifications therefor." Rhode Island Bar Ass'n v. Automobile Serv. Ass'n, 55 R.I. 122, 133-34, 179 Atl. 139, 144 (1935). See, e.g., Resh, The Bar's Duty to Prevent Unauthorized Practice, 30 UNAUTHorized Practice News 177, 187 (1964); Note, 45 CoRnerl L.Q. 126, 128 (1959); 9 VILL. L. REv. 353, 354 (1964). Unauthorized practice statutes find their legitimation as measures designed to protect the public enacted under the state's police powers. See State ex rel. Miller v. St. Louis Union Trust Co., 335 Mo. 845, 865, 74 S.W.2d 348, 357 (1934).

In 1940 the American Bar Association announced, through its Committee on Unauthorized Practice of Law, that it would institute proceedings against unauthorized practice violators only if "it can be clearly shown that such practice in the given case is resulting in injury to the public," and never solely to protect the economic interests of the profession. 26 A.B.A.J. 104 (1940).

${ }^{20}$ Johnstone, supra note 25, at 17; see, e.g., Bump v. District Court, 232 Iowa $623,639,5$ N.W.2d 914, 922 (1942).

so "It is unprofessional to represent conflicting interests, except by express consent 
To the extent that safeguards against public injury similar to those afforded by the legal profession are absent in the setting of lay estate planning services, there are grounds for the imposition of unauthorized practice sanctions. Certainly it is important that the trust officer is not subject to a binding ethical code comparable to

of all concerned given after a full disclosure of the facts. Within the meaning of this canon, a lawyer represents conflicting interests when, in behalf of one client, it is his duty to contend for that which duty to another client requires him to oppose." American Bar Association, Canon of Professional Ethics 6. See AMERICAN BAR Association, Opinions of the Committee on Professional Ethics \& Grievances 3-7 (rev. ed. 1957) (hereinafter cited as ABA OpINIons).

The force of the canons and their state bar association counterparts may vary in different jurisdictions. In some states these ethics regulations have been adopted by statute or by rules of the highest court and hence possess the full impact of law. See, e.g., Hexter Title \& Abstract Co. v. Grievance Comm., 142 Tex. 506, 510-12, 179 S.W.2d 946, 947-49 (1944) (statute empowered Texas Supreme Court to prepare code of ethics to govern professional conduct of attorneys); Rules of Professional. Conduct, Cal. Bus. \& Prof. Code following $\S$ 6076, at 405-27. A number of canons are buttressed by the fact that violation of the duty therein articulated would render the offending attorney liable to punishment under common law rules developed by court decisions. For example, the duty not to disclose confidential communications from a client (American Bar Association, Canon of Professional Ethics 37) was well established at an early date in English law. 6 Holdsworth, A History of ENGLish LAw 433 (1927). Or, the contravention of a canon may at the same time be considered a violation of public policy or breach of duty toward the court, either of the latter grounds being itself sufficient to warrant an adjudication adverse to the attorney. See, e.g., Duffy v. Colonial Trust Co., 287 Pa. 348, 135 Atl. 204 (1926). Even where no primary authority is accorded the canons, they are of persuasive effect as evidence of the standard of conduct considered obligatory by the profession. See Drinker, Legal Ethics 26-27, 30 (1953) and cases cited thercin.

The duties specified in the national or local bar association rules of conduct are frequently enforced by disciplinary proceedings initiated upon a breach and conducted according to the rules of each state. See Drinker, op. cit. supra at 34-42 for a summary description of such proceedings. These proceedings may result in permanent disbarment, suspension, or public or private censure. See PHILLIPS \& McCoy, ConDUCT OF JUDGES AND LAWYERS 94, 101, 116 (1952).

In Ohio, the Supreme Court, Court of Appeals or Court of Common Pleas is authorized to suspend or remove an attorney or reprimand him for "misconduct or unprofessional conduct in office involving moral turpitude. . . ." OHo REv. CoDE ANN. $\$ 4705.02$ (Page 1954). Moreover, the judges of such state courts are required to institute disciplinary proceedings against an attorney whose misconduct becomes known to them. Ibid. The term "moral turpitude" includes any conduct by an attorney contrary to the ethical code of his profession. In re McBride, 164 Ohio St. $419,424-25,132$ N.E.2d 113, 116 (1956) (dictum). There is, in addition, an inherent power in the supreme court and court of appeals to disbar for grounds broader than those specified by statute. See In re McBride, supra at 424, 132 N.E.2d at 116-18; In re Strong, 29 Ohio C.C. Dec. 81 (1917); cf. In re Lieberman's Disbarment, 163 Ohio St. 35, 125 N.E.2d 328 (1955). The Supreme Court of Ohio has published rules of practice under statutory authority. Rule 19 deals with professional conduct and is declared to be "binding upon all members admitted to practice law in the State of Ohio" upon pain of reprimand, suspension or disbarment for any violation. OHIO SUP. CT. R. 19. Five of the eight rules of professional conduct deal with the conflict of interest problem, $\S 6$ forbidding the representation of conflicting interests except by consent of the client. OHo SuP. CT. R. $19(6)$. 
that of the licensed attorney. ${ }^{31}$ In addition, since the primary loyalty of the trust officer is to his corporate employer, a very real danger exists that the prospect will not receive truly disinterested advice in an estate analysis report or similar communication. ${ }^{32}$ On the other hand, the preparatory training and intensive experience of the average trust officer in this concentrated area results in an expertise which may surpass that of the average attorney, for whom estate planning is only one of many areas of professional responsibility. ${ }^{33}$ The fact that a trust institution is dependent for its business on the confidence and good will of the community may serve to mitigate the danger of advice slanted more toward its own interests than toward those of its prospective customer. ${ }^{34}$ The employment by

31 It is not suggested that no ethical standards have been adopted for lay trust officers. See $A$ Statement of Principles of Trust Institutions, 57 Trust Companres 411 (1933). The Statement was approved by the Executive Council of the American Bankers Association in 1933 and was incorporated into the Banker's Code of Fair Competition. It deals principally with the responsibilities of a trust institution in the actual administration of trust accounts and lays down normative standards concerning confidential relations with customers, "disinterestedness" and fidelity in trust administration, and the general exercise of care and skill. Ibid. See Jackson, The Establishment of Cordial Relations Between the Bar and the Corporate Fiduciaries, 5 Law \& Contemp. Prob. 80, 82 (1938). See generally Harris, Code of Ethics for Trustmen, 103 TRusts \& Estates 1186 (1964).

32 The interests of the fiduciary and the grantor are divergent and conflicting as to the issues of fees, duration of the relationship, and the fiduciary's duty of care. 43 MinN. L. REv. 827, 830 (1959). More particularly, "at times the best interests of the testator are served by an outright disposition of his estate, but then there are no trustee's fees. Circumstances might make it desirable that there be two trustees, but in that event the company would have to share fees with another. It is often in the client's interest that the trust be of short duration, but those which endure over a long period of years are most profitable to the fiduciary. The client's interest might demand that the powers of the trustee be rather limited, but the company wants them as broad as possible. It is in the interest of the trust company that a provision be inserted making it liable only for actual misfeasance or gross negligence, while the client's interest might demand that the trustee be held to a high degree of care." Hicks \& Katz, supra note 25, at 82.

${ }^{33}$ See Johnstone, supra note 25 , at $34-35$. It is also worthy of note at this point that one of the factors to be considered by the Comptroller of the Currency in deciding to approve or reject a national bank's application for authorization to exercise fiduciary power, see note 7 supra, is the "nature of the supervision to be given to the fiduciary activities, including the qualifications, experience and character of the proposed officer or officers of the trust department." 12 C.F.R. $\$ 9.3$ (e) (Supp. 1966) (fiduciary powers of national banks and collective investment funds). For state regulation of banks and trust companies in Ohio, see generally OHro REv. CodE ANN. $\S \S 1111.01-.99$ (Page 1954), as amended, OHIo REv. CODE ANN. \$§ 1111.02-.28 (Page Supp. 1965).

To guarantee an adequate measure of skill and expertise in many occupations and professions states have erected educational and training barriers in the form of licensing requirements. The banking profession is not subject to this type of control. See Occupational Licensing in the States, 25 State Gov't 275, 276 (1952).

${ }^{34}$ MrN. L. Rev. 827, 831 (1959); 33 U. Cinc. L. REv. 401, 415 (1964); 
many trust companies and banks of at least some attorneys as trust personnel $^{35}$ may contribute further to an assurance of a competent and ethical estate practice by these institutions. ${ }^{36}$

Nevertheless, although several, "built-in" safeguards may thus be identified, it is also evident that they do not derive from any standards uniformly applied or adhered to in the trust-business community but rather from the individual, voluntary practices of each trust institution. The existence and vitality of these safeguards may be expected to vary considerably from case to case, leaving the pub. lic to determine at its peril the reliability of estate planning services offered by banks and trust companies.

Even assuming, therefore, that trust institutions may and do furnish improvident or self-serving advice, it remains to inquire more particularly into the likelihood and the manner of harm to the trust customer. Ordinarily, his interests will be protected by his attorney who must be consulted for the drafting of any legal document needed to implement the estate plan; ${ }^{37}$ standard procedure calls for participation of the attorney even earlier-in the discussion stage with the bank and prospect. What frequently happens, however, is that the bank recommends an attorney if the prospect has no special preference of his own; such an attorney is subjected to subtle pressures to draw up or accede to the general kind of estate plan desired by the bank, so as to be called upon for these services in the future. ${ }^{38}$ To the extent that the attorney is not

107 U. PA. L. REv. 398, 401 (1959). See McFarland, Marketing Trust Services, 103 TRUST \& Estates 1132, 1133 (1964). On the other hand, a small estate-planning corporation may be less likely to be concerned about its community stauding or reputation and therefore not feel the pinch of this prophylactic, "market place" pressure. (1959).

${ }^{36}$ See, e.g., Hamilton, The Necessity for Excellence, 98 Trusts \&. Estates 1201

${ }^{38}$ The actual value of this assurance would appear to be only marginal. The trust customer may have no dealings at all with a bank attorney, as where the latter is assigned background legal work for the trust department. And if a trust officer uses the attorney's product in advising a trust customer, there is an unauthorized practice of law violation. If, instead, the attorney does deal directly with the trust department's customers, they are still prevented from receiving the benefit of his professional competence: any communication of legal advice would again subject the trust institution to punisbment for practicing law and would further subject the attorney to disciplinary proceedings for breaching his duty of undivided loyalty and for permitting the intervention of a controlling, lay intermediary between himself and his client. See American Bar Association, Canons of Professional Ethics 6, 35; ABA OpINIONs 3-7, 33-35.

${ }^{37}$ See note 3 supra and accompanying text.

ss These competitive pressures are accentuated by the policy of some banks of 
genuinely independent, there is a substantial risk that the prospect will not be given the disinterested counsel to which he is entitled. ${ }^{39}$

Another potential source of harm consists in the possibility that the prospect, though not embarking on a full-fledged estate-arrangement program, may act himself and to his detriment on certain recommendations contained in the analysis report, as by writing a holographic will ${ }^{40}$ or by changing the beneficiary on an insurance policy. ${ }^{41}$ Even if the prospect consults an attorney, there is the danger that he will do so begrudgingly, undesirous of incurring the expense of counsel fees, and at the sole behest of the bank. Armed with an estate plan drawn out in some detail and a preconceived notion of the attorney as a necessary evil, the prospect may resist development of a healthy attorney-client relationship ${ }^{42}$ and insist that all he needs is the preparation of instruments to implement the bank's estate plan. ${ }^{43}$ The attorney will then either refuse to perform this scrivener's task, leaving the prospect with the problem of finding a lawyer willing to be a mere draftsman; or he may proceed to formulate an estate plan within the limitations imposed by an un-

retaining the attorney who prepared the instrument to represent the corporate executor or trustee.

The joint bank-bar Statement of Principles stipulates that a bank, when requested by a customer to recommend a lawyer for the legal work entailed in setting up a trust or estate, should submit several names of competent attorneys without special comment. National Conference Group, supra note 3, at $190 \mathrm{~A}$ (approved by the American Banker's Association and the American Bar Association in 1941). This rule would enable a bank in this situation to suggest attorneys known to be capable in the complex estate planning field and to avoid the waste of effort and time resulting when a lawyer unfamiliar with the intricacies of estate law is brought in. However, it does not obviate the tendency among those lawyers competing for this business to advise nomination of the bank as corporate fiduciary and other estate features which may not always be in the best interest of the client-trust customer.

${ }^{B 0}$ Not only may an attorney cater to the bank's position to enhance his competitive standing, but he may also rely heavily on the estate formula already worked out by the bank, failing to perforn the task of independent research, analysis, and formulation which it is his office to perform. Both, then, in terms of excess deference and reliance an attorney may default in his duty of providing independent counsel.

${ }^{\circ} \mathrm{A}$ holographic will satisfying the requirements for a valid testamentary instrument will be admitted to probate. E.g., In re Smith's Will, 27 Ohio Op. 520 (P. Ct. Tuscarawas County 1944).

"Other examples of "self-help" by the prospect would include the making of an inter vivos gift and the changing of the form of a bank account.

'A cooperative, and even congenial, relationship between the attorney and client is especially important in this estate practice area since a good estate plan must be based on full disclosure by the client of confidential business and family affairs and a frank discussion of what the client would like to do with his property. See TrAcHTMAN, op. cit. supra note 1 , at 3-5.

ts See 39 N.Y.U.L. REv. 364, 368 (1964). 
co-operative client. ${ }^{44}$ In neither case is the interest of the prospect adequately protected.

An interest receiving less overt emphasis but one which must be of substantial concern to the bar in its unauthorized practice campaign in this area is that of the legal profession itself. ${ }^{45}$ To dispose the public favorably toward its trust services and induce patronage, a bank or trust company advertises; not infrequently this solicitation will include, among other things, affirmations concerning the willingness and ability of the institution to give estate planning advice. ${ }^{46}$ To permit these institutions to advertise their "legal" competence while precluding attorneys from doing so not only undercuts the effectiveness of the prohibition itself but places the lawyer at a distinct competitive disadvantage. ${ }^{47}$ In addition, it tends to be destructive of the professional tenor of this legal service by accentuating the aspects of financial gain and economic rivalry. 48 The actual monetary loss suffered by the bar may be minimal due to the countervailing increase in the demand for the lawyer's draft-

\footnotetext{
" See note 42 supra. Additionally, the prospect may request only a limited service from the attorney, such as the preparation of documents for the exercise of a power of appointment. The attorney, not fully apprised of the prospect's objective (to effectuate tax savings on the basis of the estate scheme recommended hy the bank) may fail to assess the tax consequences to the prospect of legal acts requested in the broader context of this objective. As a result of his reliance on the bank's report, the prospect may thus be led into a hazardous tax position.

'S See note 27 supra and accompanying text.

t The Statement of Principles on estate planning adopted by the National Conference Group prohibits any trust institution from directly or impliedly offering to give legal advice or inviting the public by means of advertising to bring their legal problems to it. National Conference Group, supra note 3, at 191A. The fact that this has been a recurrent problem is shown by the complaints received by the National Conference Group of careless and inadvertent violations of this advertising restriction, necessitating some further statement of policy concerning advertising. Ibid.

" Solicitation of professional employment by direct or indirect means is forbidden an attorney. American Bar Association, Canon of Professional Ethics 27. Sec ABA OPINIONS 19-25; Drinker, op. cit. supra note 30, at 210-73.

"[I]t would be futile to try to protect the parties by prohibiting lawyers from soliciting legal work, and, at the same time, to tolerate such solicitation by the wholly unqualified practitioner. Moreover, the public would not be protected if this prohibition were circumvented by permitting corporations, laymen and lay agencies to claim legal competence in this field at the very same time that lawyers are forbidden to advertise. ..." American Bar Association Committee on the Unauthorized Practice of Law, Informative Opinion 1961-A: Pension and Profit Sharing Planning, 47 A.B.A.J. 1133, 1135 (1961). See Riggs, Unauthorized Practice and the Public Interest: Arizona's Recent Constitutional Amendment, 37 So. CAL. L. REv. I, 19 (1964).

s See Note, 45 Cornell L.Q. 126, 133 (1959); 107 U. PA. L. REv. 398, 401.02 (1959). See also Clark, The Effect of Unauthorized Practice of Law Upon the Ethics of the Legal Profession, 5 LAw \& Contemp. Prob. 97, 99-100 (1938); Riggs, supra note 27, at 19 n.52.
} 
ing and even consultation services as more people become convinced by the bank's salesmanship of the desirability of some form of estate planning. ${ }^{48}$ However, there remains an intangible impairment to the professionalism ideal deriving from the commercialization of the practice of estate law occurring in the absence of judicially imposed restraint.

The validity of the tests used in Green and related cases to delineate the bounds of permissible estate practice depends ultimately upon how well each is gauged to identify and safeguard against these various injuries to the public and the legal profession. The "specific information" approach adopted by the Ohio Supreme Court is grounded upon the reasonable premise that the opportunity for misapprehending and mishandling the relevant substantive law is much greater when the trust officer has the responsibility of making specific suggestions about the management and disposition of an estate than when he is confined to speaking in generalities. His conflict of interest also becomes more intense when an attempt is made to fill in, even tentatively, the features of an actual estate plan by an analysis service embodying specific advice. ${ }^{50}$ Most important, this potential harm is likely to become actualized since the recipient of the estate information will be more inclined to act on his own in reliance when it is "spelled out" and tailored to fit his particular circumstances. As to the potential problem of the prospect's attorney who may not be entirely "independent" of the bank, ${ }^{51}$ the specificity of the bank's estate analysis has little or no relation to the existence of a tacit and mutually advantageous understanding between an outside attorney and a trust officer; 52 on the other hand, it is true that the less specific the bank's recommendations are, the less likely it is that the attorney will defer without

10 This point was made by the bank in Green. 4 Ohio St. 2d at 82, 212 N.E.2d at 588. The court admitted the soundness of the proposition but concluded that it was inapposite to the question in issue, that is, whether the estate analysis program constituted the practice of law. Ibid.

${ }^{80}$ It is precisely the point at which estate advice becomes specific in relation to a particular client's circumstances that the trust officer must decide such matters as whether to recommend a corporate or individual trustee, or even a trust form of property disposition in the first instance, what duration the trust should assume, what the powers and duties of the trustee should be. All of these choices involve an inherent conflict of interest. See note 32 supra.

-1 See notes 38-39 supra and accompanying text.

En It is difficult to conceive of a compact test which would encompass this undesirable modus operandi along with other estate planning dangers. The court in Green, however, did not address itself to, or even take note of, this problem. 
reaching conclusions on his own. Finally, the threat to the professional integrity of the bar ${ }^{53}$ may be vitiated to some extent by the court's injunction which, by forbidding the bank from representing itself as capable of providing specific legal information, should have the practical effect of eliminating solicitation as to the legal service of estate planning. ${ }^{54}$

The other tests in use in this area do not appear to be well adapted to service as meaningful rules of thumb. Ill-considered advice from a trust officer is as inimical to the public when it constitutes a major item of business as when it is supplemental. Hence, the "incidental services" criterion lacks relevance to the predominant interest for the protection of which unauthorized practice restrictions exist.55 Similarly, while the receipt of some direct or indirect economic benefit by a layman for giving legal advice as contemplated by the compensation criterion may be an additional affront to the lawyer, it does not appear to have any relation to the likelihood of harm accruing to the trust customer. ${ }^{50}$

The definitional approach focusing on the "application of legal principles in more than an insubstantial way" shares a basic similarity in impact with the Green test, since such an application is surely involved in a reporting of specific legal information..$^{57}$ Depending

\footnotetext{
${ }^{53}$ See note 48 supra and accompanying text.

544 Ohio St. $2 d$ at $79-80,84-85,212$ N.E.2d at 586-87, 589-90. This prohibition would also help to equalize any competitive disadvantage thought to exist by reason of the advertising opportunities open to the bank but not to an attorney. See note 47 supra and accompanying text. This same effect could be produced if bar associa. tions were permitted vigorously to advertise the legal profession, with emphasis on the necessity for employment of competent legal counsel. Greene, Administration of Trusts-Unauthorized Practice of Law by Banks, 32 CoNN. B.J. 423, 428-29 (1958). See Johnstone, supra note 25 , at 36-42.

${ }^{55}$ For this reason, "incidental services" has been rejected as a determinative test in other unauthorized practice areas. See, e.g., Gardner v. Conway, 234 Minn. 468, 479-80, 48 N.W.2d 788, 795-96 (1951). The Green case shows that when advice of a legal complexion becomes specific in relation to a particular estate, the fact that it may be characterized as incidental, see Brief for Appellant, pp. 3-6, will not cure the unauthorized practice violation.

wa "Wrong legal advice by a layman is equally injurious whether given for or without consideration or compensation." Grievance Comm. v. Coryell, 190 S.W.2d 130, 131 (Tex. Civ. App. 1945). Accord, State ex rel. Wright v. Barlow, 131 Neb. 294, 296.97, 268 N.W. 95, 96 (1936); Grievance Comm. v. Dean, 190 S.W.2d 126, 129 (Tex. Civ. App. 1945).

57 The Ohio court in Green quoted with approval language from the Oregon case which set out the "application of legal principles" concept. 4 Ohio St. $2 \mathrm{~d}$ at 82 , 212 N.E.2d at 588. The Oregon court in applying that concept commented that while an insurance salesman could explain to a prospective customer various ways of disposing of a person's assets generally and in general terms the tax savings available from life insurance, he ordinarily could not lawfully "advise a prospective
} 
on the interpretation given by a court to the word "insubstantial," the substantiality test may be more restrictive than the Green criteria, extending to cover and prohibit even general estate analysis comments. ${ }^{58}$ To the extent of the concurrence in incidence of the two tests, the same considerations validating the Green formula should confirm the other, broader one. However, the "specific information" test can be adjudged the more useful of the two. As a practical guide, it is easier for the trust officer to abide by in terms of his actual negotiations with a prospective customer; ${ }^{59}$ and as a judicial referent, this standard is perhaps less amorphous than the "application of legal principles" concept.

While the court in Green did employ an unauthorized practice criterion possessing a measure of validity, the court's opinion is less than satisfactory. Even a summary explication of the particular injurious consequences ${ }^{60}$ of the bank's program was absent. The court disposed of the issue in litigation simply by determining that the estate analysis fell within its definition of the practice of law. ${ }^{61} \mathrm{~A}$ more useful line of inquiry would have been to consider whether, regardless of formal characterization, the challenged practices had such a detrimental effect on valued interests to justify interdiction. The mechanical, definitional approach used by the court also fails to assess the magnitude and prevalence of any existing harmful

purchaser with respect to his specific need for life insurance as against some other form of disposition of his estate ... ." Oregon State Bar v. John F. Miller \& Co., 235 Ore. 341, 347, 385 P.2d 181, 183 (1963). (Emphasis in original.)

${ }^{58} \mathrm{But}$ see id. at $344-45,385$ P.2d at 182, where the court, in discussing its "application of legal principles" test, admitted that "frequently advice given in the course of carrying on a business is shaped by a knowledge of the applicable law ..... [But] the legal ingredient in the advice may be so insubstantial as to call for the application of the principle of de minimis non curat lex." (Emphasis added.) It was the planning of a person's estate which utilized the law in more than an insubstantial way. Ibid. Compare 39 N.Y.U.L. REv. 364, 366-67 (1964).

"To require a trust officer to refrain from giving "specific legal information in relation to the specific facts of a particular person's estate," 4 Ohio St. $2 \mathrm{~d}$ at 79, 80, 212 N.E.2d at 586-87 (the full statement of the "specific information" test), is to delineate a reasonably workable standard differentiating lay estate practice from legal practice. The only problem which may arise would involve a trust officer's use of hypothetical examples and analogous situations as a means of conveying to a customer specific information relevant to the latter's estate condition without speaking directly about his particular estate. Much of the advice and information in the bank's estate analysis report in Green was apparently of this character, and while the court of appeals explicitly approved the use of "illustrative examples" of estate problems, it found the bank's suggestions objectionable as transgressing the bounds of "reasonable circumspection." 3 Ohio App. 2d at 69-70, 209 N.E.2d at 233.

"See text accompanying notes $31-49$ supra.

CI 4 Ohio St. $2 \mathrm{~d}$ at 80.81 , 212 N.E.2d at 587. 
effects, a consideration which would seem pivotal when equitable relief in the form of an injunction is sought. ${ }^{62}$ Since strained relations between the bar and lay group defendants are likely to be engendered by this kind of litigation, it is essential that courts not only clearly articulate the standards they are applying but also fully explore the policy justifications for their decisions. A frank and full judicial treatment of an unauthorized practice problem is more likely to obtain the respect of the public and lay groups involved than a superficial or mechanistic resolution, which may be interpreted as an attempt by judges to preserve the profitable business of the legal profession against impregnation. Moreover, it is only upon a foundation of respect for the formulae worked out by the courts that the most effective and desirable means of dealing with the issue of unauthorized practice-voluntary self-restraint by laymen and lay institutions operating on the fringe of legal practice and by their customers-can be established.

An evaluation of the judicial result obtained in Green should consider not only the extent of protection it affords the public but also its impact on the public's fundamental need for qualified and reasonably priced services. In the estate planning context, the question is not so much who will provide the planning and advisory services exclusively ${ }^{63}$ but rather how the lawyer and the trust officer

\footnotetext{
${ }^{62}$ For example, one might contend that so drastic a sanction as a permanent injunction is unwarranted here. The possibility that a trust customer might act on one of the few recommendations tentatively advanced in the estate analysis report which could be effectuated without the insulating intervention of an outside attorney, is arguably only tangential. This possibility and the undocumented charge of the occasional existence of a latent, self-serving "coalition" between the bank and an outside attomey recommended by it which would work to the detriment of the client-customer, may be thought insufficient grounds on which to justify curtailment of the bank's established operations. Any alleged detraction from the professional status of legal services threatened by the bank's solicitation program might be dismissed as too subtle or remote a consideration to merit any persuasive effect.

${ }^{63}$ In other unauthorized practice areas, when the bar is successful in obtaining an injunction against a lay defendant, it delimits the range of services which the latter may market and places them within the exclusive domain of the legal pro. fession. By so doing, the bar necessarily incurs a heightened responsibility to respond to the public's need for these services with at least comparable expertise and for fees which are not exorbitant. The general lack of sympathy for the bar's efforts to restrict the practice of law to the licensed, see Note, 45 CoRNELL L.Q. 126, 184 (1959), may be partly attributable to a feeling that it has not always succeeded in sustaining this responsibility. See generally Hamner, Title Insuranee Companies and the Practice of Law, 14 BAyLOR L. REv. $384 \mathrm{n.1}$ (1962), for discussion of the overwhelming voter approval in Arizona of a constitutional amendment referendum reversing, in effect, an Arizona Supreme Court decision forbidding title companies from drafting certain legal documents.
} 
will participate in a task in which both have legitimate interests and in which the optimum result may be achieved by joint effort. ${ }^{64}$ The practical consequence of the Green decision is to require an outside attorney to be brought in almost at the beginning of the dealings between the bank and its trust customer, with the bank then permitted wide latitude in discussing legal problems with the attorney and in proffering any legal advice concerning the customer's estate..$^{65}$ By thus permitting the bank and the bar each to pursue its respective calling in estate and fiduciary practice without unreasonable interference or pre-emption by the other while at the same time furnishing additional protection for the public, this result is a desirable one.

\footnotetext{
"See McLucas, Relations of Banks with the Bar, 30 UNAuthorized Practice News 189, 197 (1964); National Conference Group, Statements of Principles with Respect to the Practice of Law: Banks with Trust Functions, reprinted in 3 MARTINDALE-HuBbell, LAW Directory 190A, 191A (1966).

${ }^{o s}$ See 4 Ohio St. $2 \mathrm{~d}$ at $83,85,212$ N.E.2d at $588,590$.
} 